\title{
Taxonomy and song of the cicada Ayesha serva (Walker, 1850) from the coasts of northern Sundaland
}

\author{
Hans Duffels \& Tomi Trilar
}

\begin{abstract}
The genus Ayesha belongs to the tribe Dundubiini and is distinguished from other genera of the tribe by the spatulate and strongly overlapping male opercula. The synonymy of three species, Cosmopsaltria vomerigera Breddin, 1901, Dundubia lelita Kirkaldy, 1902 and Cicada elopurina Distant, 1888, which are treated as junior synonyms of $A$. serva (Walker, 1850) in the literature, is confirmed. Two other species, $A$. spathulata Stål, 1870 and A. operculissima Stål, 1870, are synonymized here with $A$. serva, so that Ayesha now becomes a monotypic genus. Ayesha serva is redescribed and recorded from Greater Natuna Island, the northern parts of Borneo and Sulawesi and the southern Philippines; the species is mainly found in trees on the beach, in mangroves and other coastal forests. The broad band long lasting monotonous calling song has a very simple and constant pattern. It consists of a fast repetition of many echemes of duration from 41.7 to $79.0 \mathrm{~ms}$, which are composed of 8 to 19 pulses with a repetition rate of 240 pulses per second.

Hans Duffels*, Naturalis Biodiversity Center, Department of Terrestrial Zoology, P.O. Box 9517, NL-2300 RA Leiden, The Netherlands. hans.duffels@ncbnaturalis.nl Tomi Trilar, Slovenian Museum of Natural History, Prešernova 20, P.O. Box 290, SI-1001 Ljubljana, Slovenia. ttrilar@pms-lj.si
\end{abstract}

\section{Introduction}

Ayesha serva (Walker, 1850) is known from Greater Natuna Island between the Malayan Peninsula and Borneo, from the coasts of North Borneo (Malaysia: Sabah and Sarawak; Brunei) and North Sulawesi, and the southern Philippines. It can be found in shrubs and trees on the beach, in mangroves and other coastal forests. The cicadas are difficult to spot and to catch but the monotonous sound of the males and the high number of their nymphal skins on the tree trunks may betray their presence. Since its description as Dundubia serva by Walker (1850), the species has been described five times under different names, viz., Cosmopsaltria spathulata Stål, 1870, Cosmopsaltria operculissima Stål, 1870, Cicada elopurina Distant, 1888, Cosmopsaltria vomerigera Breddin, 1901 and Dundubia lelita Kirkaldy, 1902. The present paper synonymizes all these names with
Ayesha serva and provides a description of the species and an analysis of its calling song.

\section{History of the genus}

The genus Ayesha was described by Distant (1905) for Cosmopsaltria spathulata from the Philippines. In 1906, Distant synonymized three species with Ayesha spathulata: Cosmopsaltria vomerigera from $\mathrm{Su}-$ lawesi, and Dundubia lelita and Cicada elopurina, both from Borneo. In the same publication Distant (1906) transferred two species to Ayesha: Dundubia serva described from Korea and Cosmopsaltria operculissima from Borneo. Moulton (1923) followed Distant and distinguished two species of Ayesha in his 'Cicadas of Malaysia': A. spathulata from the Philippines, Borneo, Greater Natuna Island and Sulawesi and A. operculissima from Borneo. Ayesha serva from 
Korea was mentioned by Moulton (1923) as another species of the genus, but it was not discussed.

\section{Material and methods}

The institutions listed below are the depositories of the material studied. The abbreviations have been used in the lists of material and throughout the text.

BMNH Natural History Museum, London

MCZ Museum of Comparative Zoology, Cambridge, MA

MZS Museé Zoologique de la Ville de Strasbourg, Strasbourg

NHRS Naturhistoriska Riksmuseet, Stockholm

NHMW Naturhistorisches Museum, Wien

PMSL Prirodoslovni muzej Slovenije (Slovenian Museum of Natural History), Ljubljana

RMNH Naturalis Biodiversity Center (former Rijksmuseum van Natuurlijke Historie), Leiden

SAM South Australian Museum, Adelaide, SA

UZMK Universitets Zoologisk Museum, Copenhagen

ZMAN Zoological Museum, Amsterdam

Songs of $A$. serva were recorded in the field using a parabolic mono microphone Telinga Pro $3 \mathrm{M}$ (in the year 1996) and a parabolic stereo microphone Telinga Pro V (in 1999 and 2003) (parabola diameter $57 \mathrm{~cm}$ ) connected to Sony DAT-recorder TCD-D3 (sampling rate $48 \mathrm{kHz}, 16 \mathrm{Bit}$ dynamic range). In the lab, DAT recordings were transferred to the Hard Disk of a Power Macintosh G4 computer through an Audiomedia III sound card using Pro-Tools 5.0 (Digidesign, Avid Technology) software. Afterwards the song files were transferred to a PC computer and the software used for analysing the song signals was Raven 1.2.1 (Cornell Lab of Ornithology) and Seewave package (Sueur et al. 2008) as a part of $\mathrm{R}$ software platform ( $\mathrm{R}$ Development Core Team 2008). For statistical evaluation we used Excel 2000 (Microsoft).

The recordings were made on the island of Borneo: at Tanjung Aru beach near Kota Kinabalu, Sabah, on July, $3^{\text {rd }} 1996$ around 13:00 h and March, $6^{\text {th }} 2003$ around 16:00 h, at Telok Assam in Bako National Park, Sarawak, on June, 6 ${ }^{\text {th }} 1996$ around 15:30 h and on Pulao Sapi in Tunku Abdul Rahman National Park, just offshore Kota Kinabalu, Sabah, on April, $8^{\text {th }} 1999$ around 15:30 h (Fig. 16). The duration of the recordings was between $40 \mathrm{~s}$ and $2 \mathrm{~min}$ $31 \mathrm{~s}$, while altogether was measured $17 \min 4 \mathrm{~s}$ of $A$. serva calling songs.

Two males of $A$. serva from Tanjung Aru, which were first recorded and then collected, are labelled:
Malaysia, Kota Kinabalu, Tanjung Aru, $05^{\circ} 54^{\prime} \mathrm{N}$ $116^{\circ} 04^{\prime} \mathrm{E}$, 6.iii.2003, $5 \mathrm{~m}$, T. Trilar \& K. Prosenc Trilar and deposited in the collection of the Slovenian Museum of Natural History (PMSL) in Ljubljana, Slovenia. All sound recordings are stored in the Slovenian Wildlife Sound Archive housed in the Slovenian Museum of Natural History (PMSL). Samples of the song are available on the web page Asian cicadas (http://www2.pms-lj.si/ staff/bioacoustics/asian.html).

Data on the distribution of the species were derived from the authors' 'Biodiversity Database of the Cicadas of South East Asia and the West Pacific', and plotted on maps of ADC-Worldmap version 2.0 vol. 4 Southern Asia \& Australia with the program MapInfo version 11 for Windows XP. The localities and other data from the specimen labels in the database are filed in the program FileMaker Pro 6.0. Geographical information has been retrieved from the following sources: 'Malaysia, Travel and Holiday Planner' (Anonymous 1996), 'The Times Comprehensive Atlas of the World' (Anonymous 1999) and from Global Gazetteer Version 2.2 (www.fallingrain.com).

The terminology adopted in this paper for external features of the body and the male genitalia follows that of Duffels $(1977,1983)$ and Moulds (2005).

\section{Taxonomy}

\section{Genus Ayesha Distant}

Ayesha Distant, 1905: 63. Type species by original designation: Ayesha spathulata (Stål, 1870).

Ayesha; Moulton 1923: 96; Metcalf 1963: 560, 561; Nast 1972: 142; Duffels \& Van der Laan 1985: 131; Moulds 2005: 391, 432; Lee 2009: 2630; Lee \& Hill 2010: 299, 300, 302.

\section{Description of genus}

Medium sized cicadas, body length male: 25$28 \mathrm{~mm}$, female $24-29 \mathrm{~mm}$. Head slightly broader than pronotum and distinctly broader than mesonotum. Postclypeus moderately produced. Vertex with median black spot. Rostrum reaching just beyond trochanter of middle legs. Pronotum with a pair of fairly narrow, black to black-brown, central fasciae. Mesonotum with narrow median fascia, which is widened at half its length, a pair of paramedian fasciae, which are very variable in width, a pair of black, round spots in front of anterior angles of cruciform elevation and a pair of, often indistinct, lateral fasciae. Male operculum spatulate, strongly narrowed at one third of its length and strongly widened at two thirds of length; apical part broadly rounded 
and oblique with broad, dark brown coloration along apical and medial margins; lateral part of operculum with white wax. Apical parts of both opercula strongly overlapping. Tergites of male and female shiny brown without distinct marking. Timbal coverings dark brown and not shiny. Ventral side of male and female abdomen ochraceous to light brown.

Duffels \& Van der Laan (1985), Moulds (2005) and Lee \& Hill (2010) placed Ayesha in the tribe Dundubiini Atkinson, 1886.

\section{Ayesha serva (Walker, 1850)}

Figs 1-16

Dundubia serva Walker, 1850: 60, Holotype ơ: 'Dundubia/serva, W. type', 'Type' [round label with green circle; print] [locality label 'Corea' missing; head missing] (BMNH) [examined].

Cosmopsaltria spathulata Stål, 1870: 709, Lectotype $\sigma^{7}$ (designated here): 'Ins./Philipp.', 'Semper', 'Cosmopsaltria/spathulata/Stål.', 'Typus' [print in black in black cadre on red paper], 'NHRSHEMI/000000006' (NHRS). [examined photographs of lectotype and paralectotypes].

Cosmopsaltria operculissima Distant, 1881: 641, Holotype $\sigma^{7}$ : 'N. Borneo/Pryer', 'operculis-/sima Dist.', 'Type' [round label with red circle; print], 'Distant Coll./1911-383' [print] [the type is missing the locality label Sandakan] (BMNH) [examined]; Distant 1891: 61, pl. v Figs 5, 5a-b.

Cicada elopurina Distant, 1888: 297, Holotype o: 'Elopura/[two other lines of label illegible]', 'elopurina/Dist.', 'Distant Coll./1911-383', 'Type' [round label with red circle; print] (BMNH) [examined].

Cosmopsaltria spathulata; Distant 1890: 61, pl.vi Figs 3a, b;

Cicada elopurina; Distant 1892: 98, pl.xii Figs 5, 5a. Cosmopsaltria vomerigera Breddin, 1901: 105, Holotype $0^{\top}$ : Nord Celebes, Buol, vii.1894, Sarasin [not examined].

Dundubia lelita Kirkaldy, 1902: 54, Holotype ơ: British Borneo [not examined].

Ayesha spathulata; Distant 1905: 63; Distant 1906: 57 (= Cicada elopurina Distant, Dundubia lelita Kirkaldy, Cosmopsaltria vomerigera Breddin); Distant 1912: 46, pl. 5 Figs 39, 39a-c; Moulton 1923: 72, 96, 97, 167; Metcalf 1963: 561, 562; Lee 2009: 2630, Fig. 8, 2631.

Ayesha operculissima; Distant 1906: 58; Moulton 1923: 96, 97, 167; Metcalf 1963: 560.

Ayesha serva; Distant 1906: 57, 58; Distant 1890: 60, 61; Distant 1891: pl. xi, Fig. 3b; Moulton 1923: 97; Metcalf 1963: 560, 561; Nast 1972: 142; Duffels \& Van der Laan 1985: 131; Lee 1995: 7, 8, 12; Lee 1999: 13; Lee 2008: 462.

\section{Lectotype designation for Ayesha spathulata (Stål)}

Dr Gunvi Lindberg (NHRS) kindly sent us photographs of the type specimens of Ayesha spathulata, viz., one male labelled 'Typus' (Figs 1-3), one female labelled 'Allotypus' (Figs 4-6) and one female labelled 'Paratypus'. She also wrote at an earlier occasion (Duffels 2010): ...' all curators seem to agree that the [type] labels are from the $20^{\text {th }}$ century'. In order to establish the identity of $A$. spathulata, we designate the male specimen labelled 'Typus' as the lectotype of $A$. spathulata.

\section{Synonymy}

For the present paper we have studied the holotype of Ayesha serva from Korea and the holotypes of $A$. operculissima and A. elopurina, both described from Borneo, and photographs of the lectotype and paralectotypes of $A$. spathulata. We have not examined types of Cosmopsaltria vomerigera from Sulawesi, and Dundubia lelita from North Borneo. Examination of the holotype of $C$. elopurina confirms the synonymy of this species to $A$. spathulata as already established by Distant (1906). Study of Ayesha material from Borneo and Sulawesi (see list of material examined) sustains the synonymy of Dundubia lelita from Borneo, and Cosmopsaltria vomerigera from $\mathrm{Su}-$ lawesi to $A$. spathulata, as was also proposed by Distant (1906).

Moulton (1923) distinguished two species of Ayesha: A. spathulata from the Philippines, Borneo, Greater Natuna Island and Sulawesi with short male opercula reaching the $6^{\text {th }}$ abdominal segment and A. operculissima from Borneo with long male opercula reaching the tip of the abdomen. However, our study demonstrates that the relative length of the male operculum in Ayesha cannot be used to separate species. Due to telescoping of the abdominal segments, specimens may differ in the relative length of abdomen and operculum, though it is not the operculum, but the male abdomen in the first place, that shows variability in length. Examination of specimens with a normal and a more or less telescoped abdomen among a series of Ayesha from Toli Toli, Sulawesi proved that these specimens are conspecific. Ayesha serva from Korea was mentioned by Moulton (1923) as another species of the genus, but it was not discussed. Dundubia serva was originally described from Korea by Walker (1850). In his publications on the cicadas of Korea, Lee (1995, 1999, 2008), concluded that the type specimen was mislabelled and that Ayesha serva does not occur in Korea. Two other species also described by Walker (1850) 

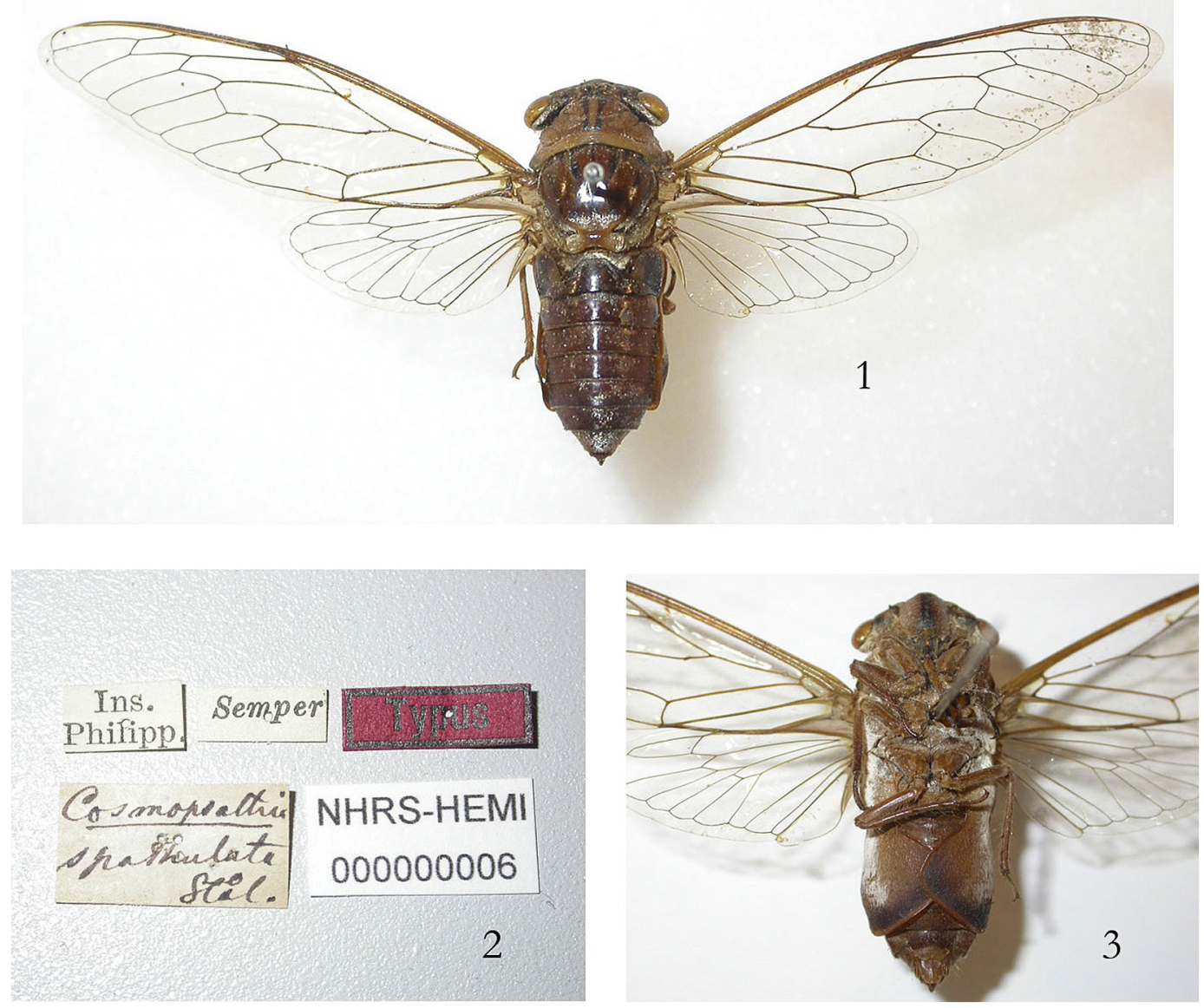

Figs 1-3. Ayesha serva, male lectotype of A. spathulata. - 1, dorsal view; 2, labels; 3, ventral view (Copyright Swedish Museum of Natural History, Stockholm (NHRS)).

from Korea, Cryptotympana aquila and Orientopsaltria phaeophila, do not occur in Korea either (Lee 1995), both are Sundaland species (Hayashi 1987; Duffels \& Zaidi 2000). It is most likely that the holotype of Dundubia serva also originates from Sundaland.

Study of the external morphology, body marking and male genitalia of the types of $A$. serva and A. operculissima, the photographs of the types of A. spathulata, and additional material from Greater Natuna Island, Borneo, Sulawesi and the Philippines (see list of material examined) lead to the conclusion that the latter two species are junior synonyms of A. serva. Since Dundubia serva is the oldest available name among the six synonymous names discussed above, Ayesha serva should be the valid name. In our opinion all specimens of Ayesha studied belong to this species.

\section{Description (Figs 1-9)}

Ground colour of head and pronotum ochraceous to greenish, mesonotum dark brown to castaneous, abdomen of male and female light to dark brown. Underside of head and thorax covered with short and fairly long white setae.

Head. Vertex with median, round, black spot enclosing ocelli, anterior margin of median spot convex and reaching to frontoclypeal suture, posterior part of median spot broadly connected with black coloration along posterior margin of head; a median lanceolate, ochraceous spot extends from median ocellus to posterior head margin. A pair of triangular black-brown marks covers the supra-antennal plates and small parts of the vertex lobes. Proximal apices of these triangular marks may be connected with a pair of squarish black-brown marks, which are attached to lateral parts of posterior margin of head and broadly 

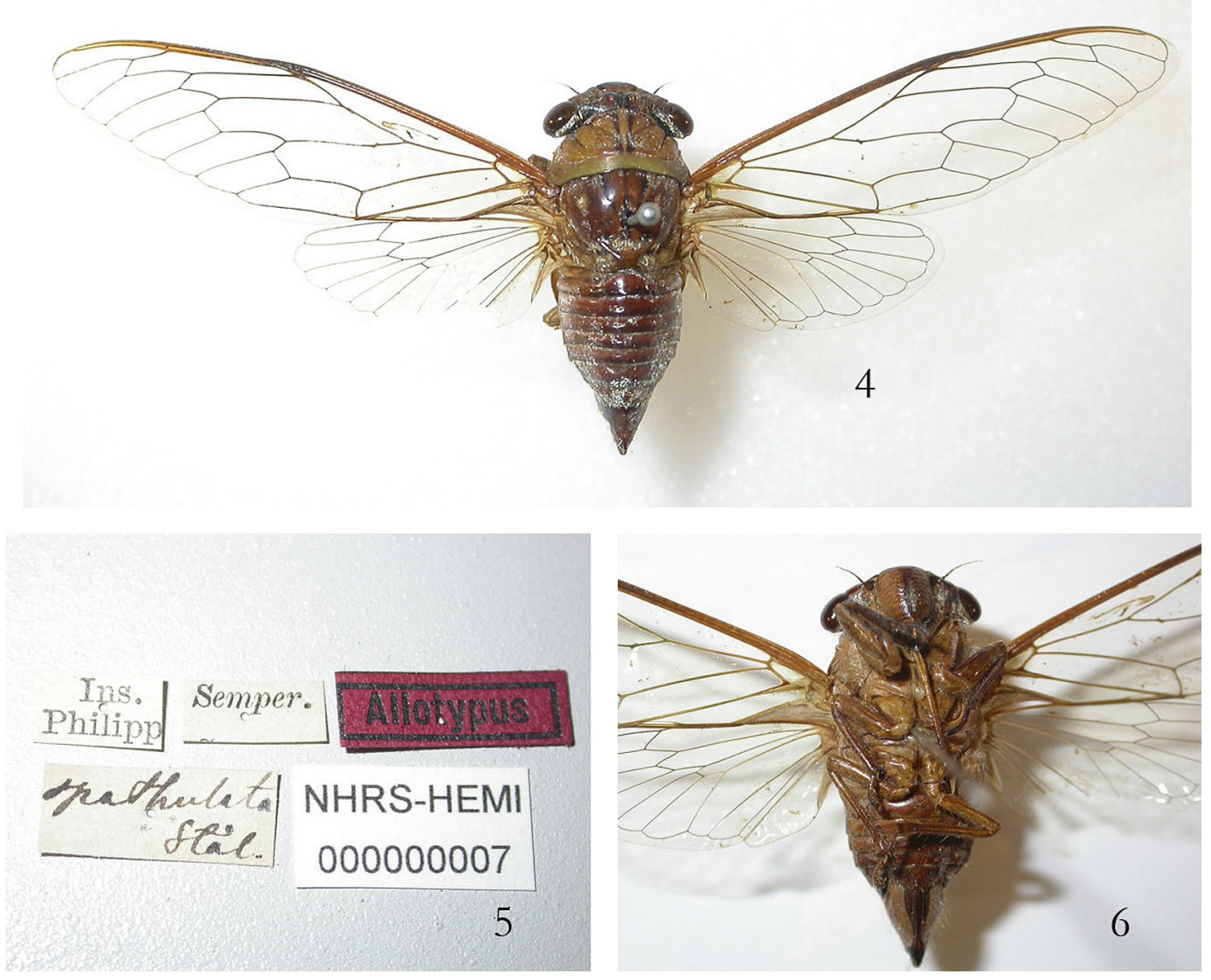

Figs 4-6. Ayesha serva, female allotype of $A$. spathulata. - 4, dorsal view; 5, labels; 6, ventral view (Copyright Swedish Museum of Natural History, Stockholm (NHRS)).

connected with a fairly broad, black fascia extending along whole margin of eye. Anterior part of postclypeus with upper 5-7 transverse grooves of either side usually more or less black but sometimes brown; a black to brown quadrangular mark often covers the upper 2-4 transverse grooves of each side; quadrangular marks separated by a median, yellow, oval spot. A median brown to black fascia extends, and usually widens, from this oval spot to clypeal suture. Anteclypeus black but median keel and anterior margin yellow. Gena with triangular, black to brown mark narrowing from eye margin to antenna. Basal half or two-thirds of lorum black. Rostrum with brownish apex and reaching just beyond trochanter of middle legs.

Thorax. Pronotum. Central fasciae fairly narrow, black to black-brown, strongly widened and fused at black to black-brown anterior pronotum margin; proximal ends kidney-shaped and almost fused at anterior margin of pronotal collar. Some spec- imens with pair of faint brownish marks between anterior and posterior oblique fissures. Pronotal fissures unmarked or light brownish. Posterior margin of pronotum and margin of lateroproximal bend of pronotum collar black to black-brown.

Mesonotum. Marking only slightly darker than ground colour. Median fascia reaching from anterior margin of mesonotum to level of anterior angles of cruciform elevation; the fascia is very narrow in anterior one third, widens to 4-5 times its anterior width at half or two thirds of its length and slightly narrows again to the posterior.

Paramedian fasciae very variable in width, anteriorly equally broad to many times as broad as anterior end of median fascia, and slightly converging from anterior margin of mesonotum to two fifths of mesonotum length, in some specimens paramedian fasciae widest at half their length but apical part always narrowing to the apex that is sometimes recurved. A pair of black, round spots in front of ante- 
rior angles of cruciform elevation. Lateral fasciae often very vague, brownish, either more or less continuous from just below anterior mesonotum margin to anterior angles of cruciform elevation or broken up in several spots or consisting of only one short line or completely lacking. A pair of dark brown to blackbrown, sometimes fairly long and narrow, triangles at anterior mesonotal margin between paramedian and lateral fasciae.

Legs. Ochraceous to brownish. Under-ridge of fore femur with a fairly long and narrow, semi-erect, brown spine at one third of its length, a shorter, triangular spine at three-fourths of length and a very small spine next to the latter; spines connected by black line. Tibiae of all legs more brownish to their distal ends. Tarsi of fore and middle legs brown to black, those of hind legs ochraceous.

Tegmina and wings. Hyaline without spots, venation ochraceous to brownish.

\section{Male}

Operculum (Fig. 7). Spatulate, strongly narrowed at one third of its length to 0.7 times its basal width and strongly widened in the apical part to 2.5 times its basal width. Lateral and medial margins strongly concave at one third of their length, lateral margin strongly convex and medial margin very strongly convex at two thirds of their length. Apical margin broadly rounded and oblique and reaching to one third of abdominal segment 6 or to half-length of segment 7. Apical parts of opercula strongly overlapping. Surface brown with broad, dark brown coloration along apical and medial margins; lateral part of operculum covered with white wax from base of operculum to the dark brown coloration.

Abdomen. Tergites shiny brown, timbal coverings dark brown and not shiny. Tergite 3 with a pair of dark brown, more or less round, lateral spots. Tergites 5-7 with a pair of smaller, often less distinct,
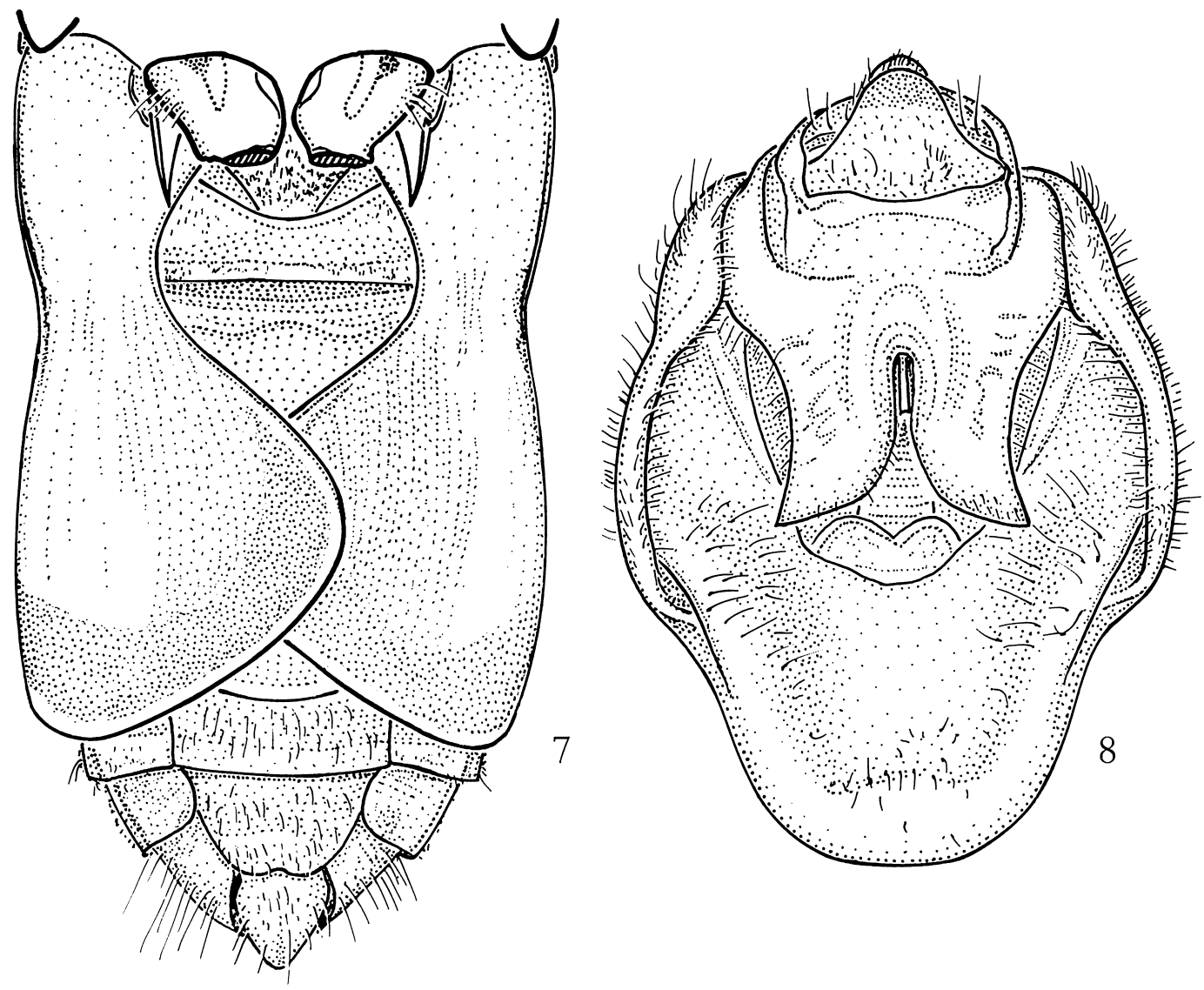

Figs 7, 8. Ayesha serva, male, Tanjung Aru. - 7, abdomen with opercula in ventral view; 8 , male pygofer with pair of claspers in ventral view (drawing Dick Langerak). 
lateral spots. Ventral side of abdomen ochraceous to light brown.

Genitalia (Fig. 8). Pygofer ochraceous to light brownish; lateral pygofer lobes rounded. Uncus lobes with a pair of juxtaposed or somewhat apart, lobes, apically taper to a laterodistal sharp apex; lateral margins of uncus lobes weakly concave, medial margin convex.

\section{Female}

Operculum. Ochraceous to light brown, reaching to half length abdominal segment 3. Lateral margin weakly sinuate, posterior margin fairly narrowly rounded, and straight to weakly convex toward meracanthus.

Abdomen. Tergites shiny brown, posterior one-thirds or halves of tergites 2-8 darker brown than anterior parts. Segment 9 with a pair of more or less distinct, long, dark brown to black-brown triangles reaching from anterior segment margin to four fifths of segment length. Sternite 7 with a pair of paramedian dark brown spots.

Measurements $\left(7 \sigma^{\top}\right.$ 6o, in mm). Body length $\sigma^{\top 7} 25.4-$ 28.3, o 24.4-29.2; head width $\sigma^{7}: 10.3-10.8$, 우 $10.0-11.5$; pronotum width $\sigma^{3}: 9.1-10.5$, o $9.7-$ 11.4; tegmen length $\sigma^{7}: 34.9-37.8$, o 34.8-40.6.

\section{Exuviae}

Exuviae (Figs 9, 17-18) light brown. Abdomen fairly slender. Fore tibia with fairly long and strong apical tooth with shallow incision at its base and with sharp blade along its lower margin (Fig. 9). Fore femur with strong, moderately curved, proximal hook, intermediate tooth triangular, most proximal tooth of femoral comb also triangular and about half as long as intermediate tooth, next 5-8 teeth of femoral comb shorter, narrow and rounded apically, most distal tooth of comb widening from base to apical part

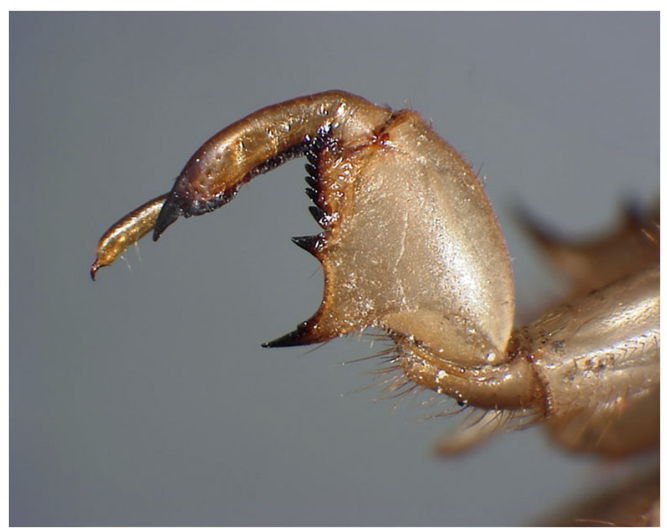

Fig. 9. Ayesha serva, fore leg of exuviae in lateral view, Kota Kinabalu, Tanjung Aru (photo Tomi Trilar). as a reversed triangle (Fig. 9). Apex of tibia of hind leg with four strong spines. Male segment 10 with a pair of proximal protrusions. Length exuviae $\left(40^{7}\right.$ 3o): male: $23.6-26.5 \mathrm{~mm}$, female: $25.5-26.5 \mathrm{~mm}$.

\section{Description of the song}

Altogether 17 recordings of at least ten different individuals were used for analyses. The exact number of individuals recorded is almost impossible to determine when animals are chorusing in a canopy. Most of the recordings consist of the middle constant part of the song (Figs 10-13) and only two of them include the end of the song (Fig. 14).

Time parameters. The broad band long lasting monotonous calling song of $A$. serva has a very simple and constant pattern (Figs 10-13) and consists of a fast repetition of many echemes of duration between 41.7 and $79.0 \mathrm{~ms}$ (mean and standard deviation: $58.7 \pm 5.8 \mathrm{~ms}, N=5449$ ) (Fig. 15a). The duration of intervals between echemes is from 39.6 to $81.8 \mathrm{~ms}$ (51.6 $\pm 7.4 \mathrm{~ms}, N=5449)$ (Fig. 15b). The echeme repetition rate is $9 \pm 0.5$ echemes per second $(\mathrm{min}=$ 7.8, $\max =9.4, N=8$ ) and the ratio between echeme and interval duration is between 0.6 and 1.9 $(1.2 \pm 0.2, N=5449)$. Echemes are composed of pulses. We counted out the pulses in the first 20 echemes of each 200 echemes. The number of pulses per echeme is 8 to $19(14.1 \pm 2.7, N=$ 640) (Fig. 15c) and its repetition rate 240 pulses per second. This is true for all the calling songs from Tanjung Aru, Telok Assam and one of the calling songs out of three from Pulao Sapi.

Figure $15 \mathrm{c}$ shows that echemes according to the number of pulses fall into two groups. The echemes of one calling song from Tanjung Aru and one from Telok Assam consist of 9 to 12 pulses (echeme duration $59.1 \pm 4.7$ ), while all others from Tanjung Aru, Telok Assam and one of the calling songs out of three from Pulao Sapi consist of 12 to 19 pulses (echeme duration 61.0 \pm 4.7).

Two calling songs from Pulao Sapi have substantially different time parameters. Echeme duration of the first is from 51.3 to $107.1 \mathrm{~ms}(77.7 \pm 10.2 \mathrm{~ms}$, $N=1155)$, interval duration between 37.8 and $80.1 \mathrm{~ms}(53.3 \pm 5.4 \mathrm{~ms}, N=1154)$, echeme repetition rate 7.6 echemes per second and the ratio between echeme and interval duration 0.8 to 2.6 $(1.5 \pm 0.3, N=1154)$. The number of pulses per echeme is from 13 to $29(19.6 \pm 2.7, N=120)$ and its repetition rate 253 pulses per second.

In the second the echeme duration is between 60.2 and $114.8 \mathrm{~ms}(80.0 \pm 11.0 \mathrm{~ms}, N=847)$ (Fig. 15d), interval duration 40.8 to $72.9 \mathrm{~ms}$ (51.0 \pm $3.7 \mathrm{~ms}, N=847$ ) (Fig. 15e), echeme repetition rate 7.1 echemes per second, the ratio between echeme and interval duration is from 1.1 to $2.6(1.8 \pm 0.2$, 

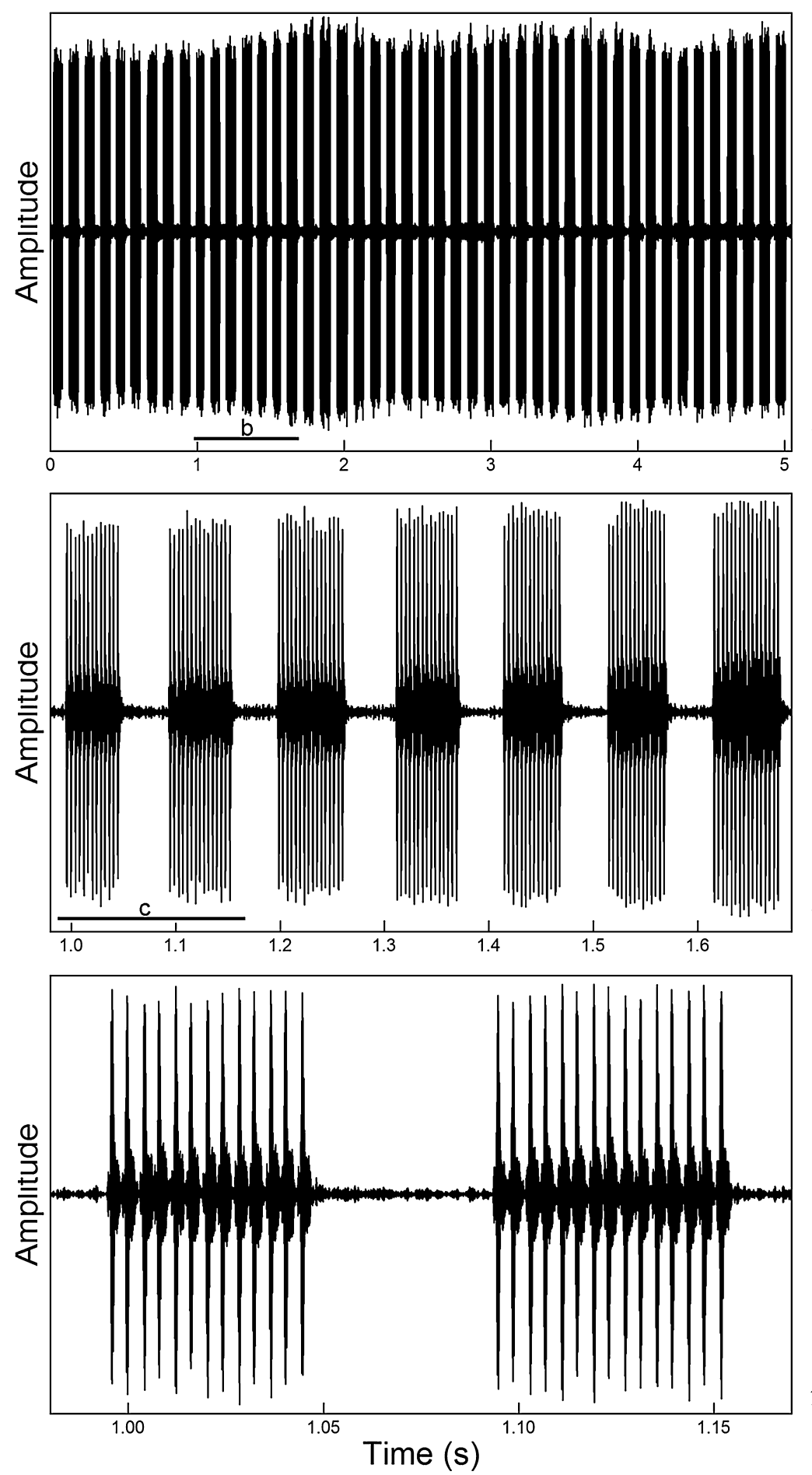

Figs 10-12. Song of Ayesha serva from Borneo. - 10, spectrogram of a typical middle part of the song; 11, enlarged seven echemes from the middle part of the song; 12, enlarged two echemes from the middle part of the song with clearly visible pulses. 


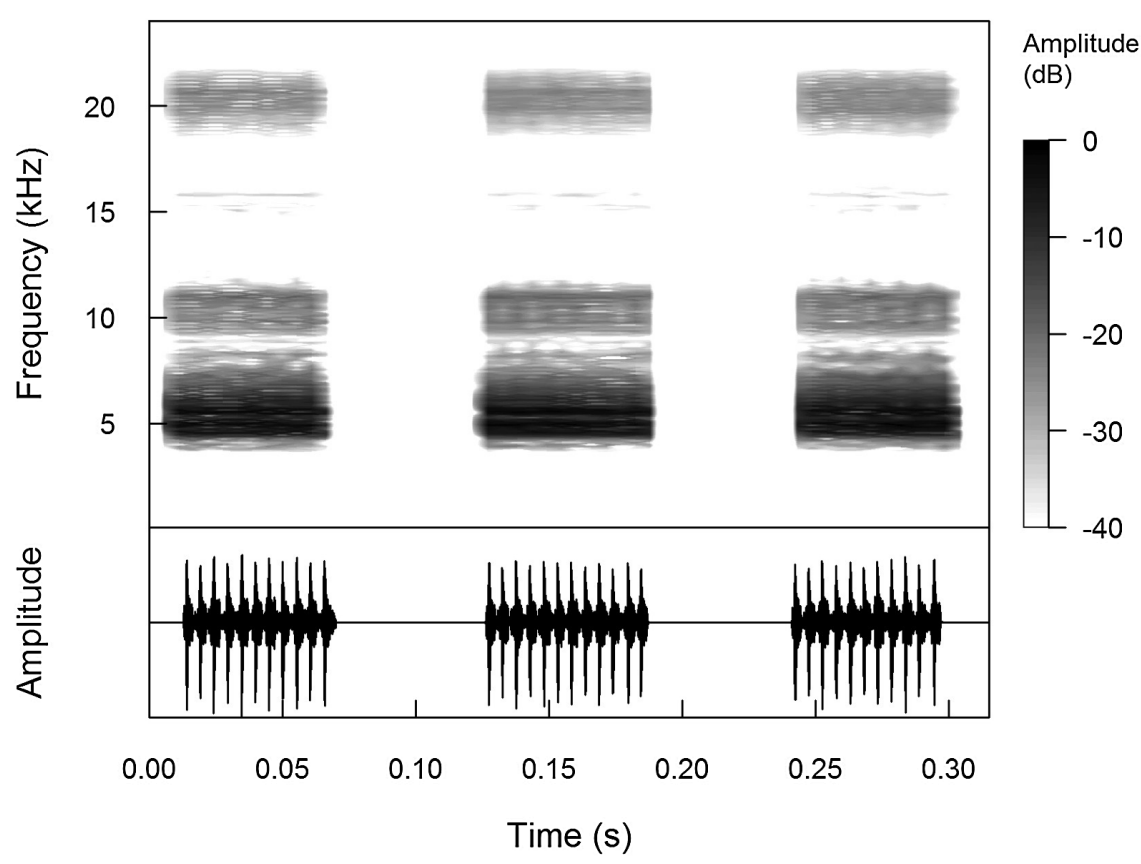

Fig. 13. Song of Ayesha serva from Borneo. Spectrogram and oscillogram of three echemes from the middle part of the song with clearly visible pulses. (Frequency analysis parameters: Hamming window, overlap $=50 \%$, window length for the analysis $=512$ ).

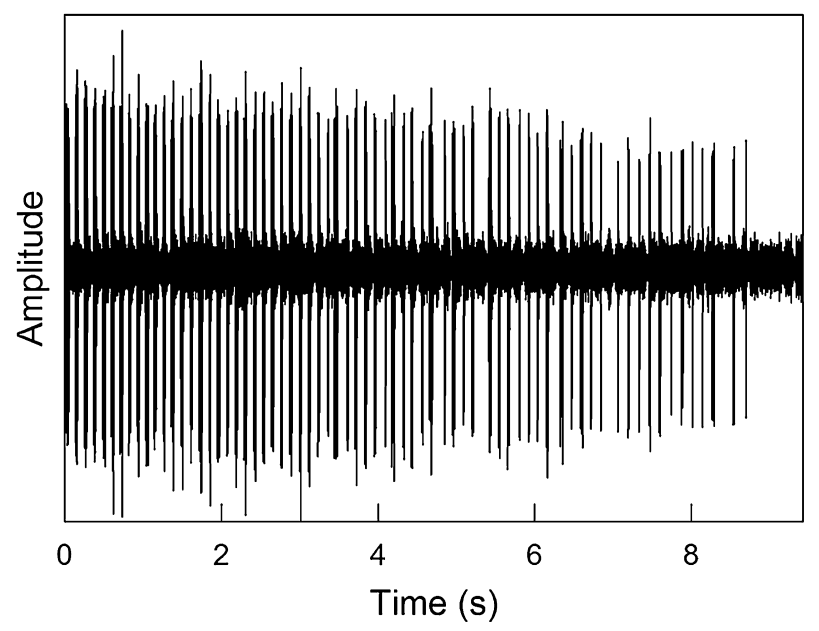

Fig. 14. Song of Ayesha serva from Borneo. Spectrogram of the end of the song.

$N=847)$. The number of pulses per echeme is between 16 to $29(23.3 \pm 2.6, N=100)$ (Fig. $15 \mathrm{f})$ and its repetition rate 253 pulses per second.

Frequency range. The broad frequency spectrum of A. serva calling song has a fundamental frequency at about 4.59 and $6.28 \mathrm{kHz}(5.75 \pm 0.39 \mathrm{kHz}$,
$N=632$ ) with pronounced three higher harmonics. Dominant is the fundamental frequency, followed by the $1^{\text {st }}$ and $3^{\text {rd }}$ higher harmonics (intensity approximately $25 \mathrm{~dB}$ lower), while the $2^{\text {nd }}$ higher harmonics is less prominent and is often completely masked by the noise from the environment. 



Fig. 15. Song of Ayesha serva from Borneo. Histogram of echeme duration, interval duration and number of pulses per echeme. Normal calling songs - all the calling songs from Tanjung Aru, Telok Assam and one of the calling songs out of three from Pulao Sapi; Longer calling song - the second calling song from Pulao Sapi (see explanation in the text). (The $x$-axis has the same scale for both song types, the scales on the $y$-axis are not equal, due to different number of measurements). 


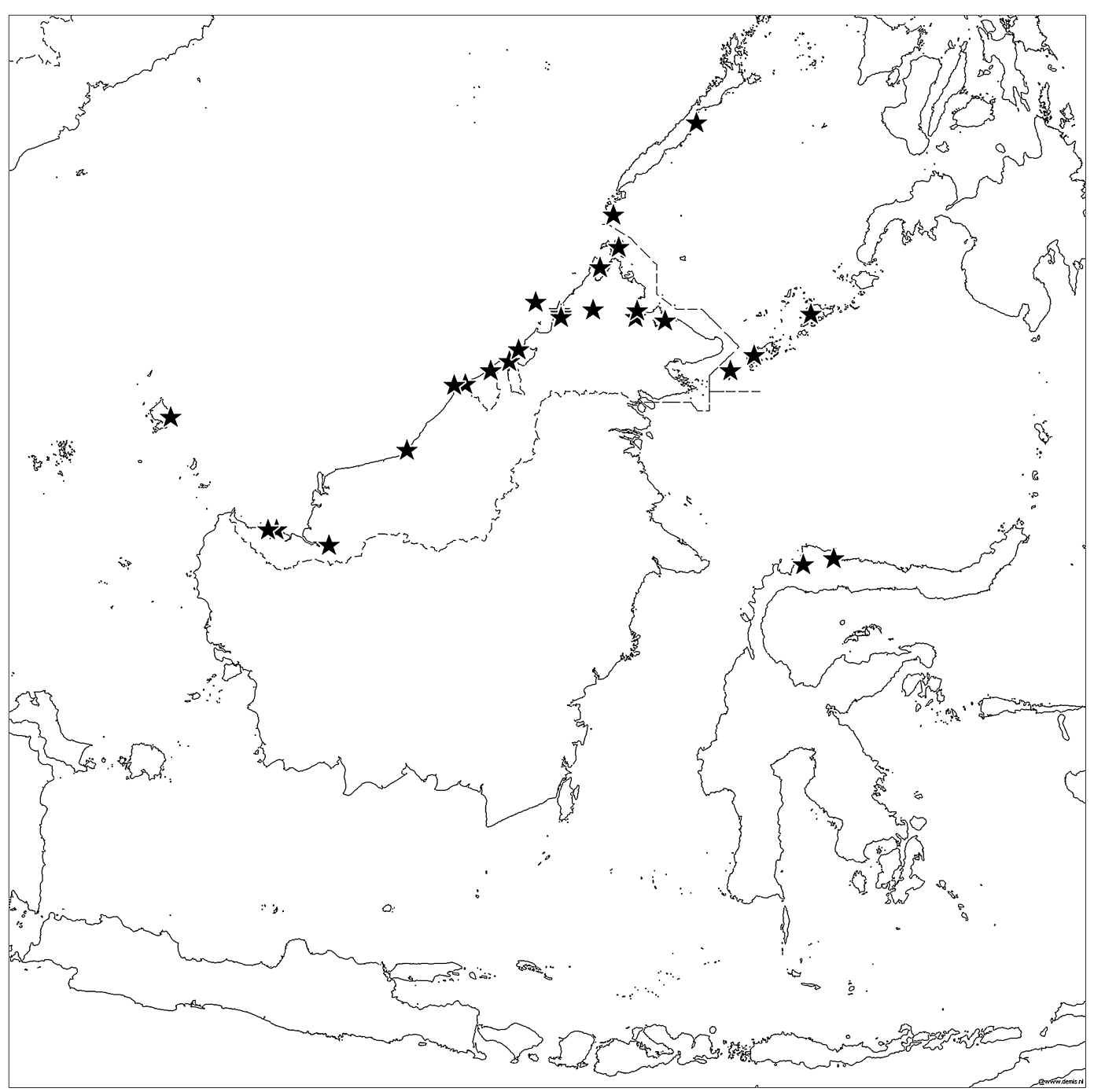

Fig. 16. Distribution map of Ayesha serva (map by Rob Portegies).

\section{Distribution, ecology and behaviour}

Ayesha serva occurs in Greater Natuna Island (between the Malayan Peninsula and Borneo), northern Borneo (Malaysia: Sabah and Sarawak; Brunei), from Banguey, Balabac and Palawan islands north of Borneo, from the Sulu Archipelago (Sipankot, Tawi Tawi and Jolo islands) between Borneo and the Zamboanga peninsula of Mindanao and from northern Sulawesi (Fig. 16).

Ayesha serva is a coastal species. One of us ( $\mathrm{T}$. Trilar) recorded the song and collected specimens of this species from trees behind the beach at Tanjung Aru near Kota Kinabalu, Sabah. The song was also recorded from coastal trees at Pulao Sapi in Tunku Abdul Rahman N.P., just offshore Kota Kinabalu,
Sabah and in the mangroves Telok Assam in Bako National Park, Sarawak. Martjan Lammertink and Bpk Usnan collected $A$. serva (with stick and glue) in coastal forest consisting of secondary growth with coconut palms in Greater Natuna Island. Lee (2009) found the species in dry coastal forest $(220 \mathrm{~m})$ and limestone forest $(10 \mathrm{~m})$ in Palawan.

The cicada exuviae found in great numbers on tree trunks (Figs 17, 18) at Tanjung Aru beach near Kota Kinabalu are attributed to $A$. serva since this was the only cicada species singing on the beach.

Ayesha serva is not a very persistent singer and it is chorusing only during the day on the trees along the beach and always away from the forest. The males can be quiet for one or two hours and then one 

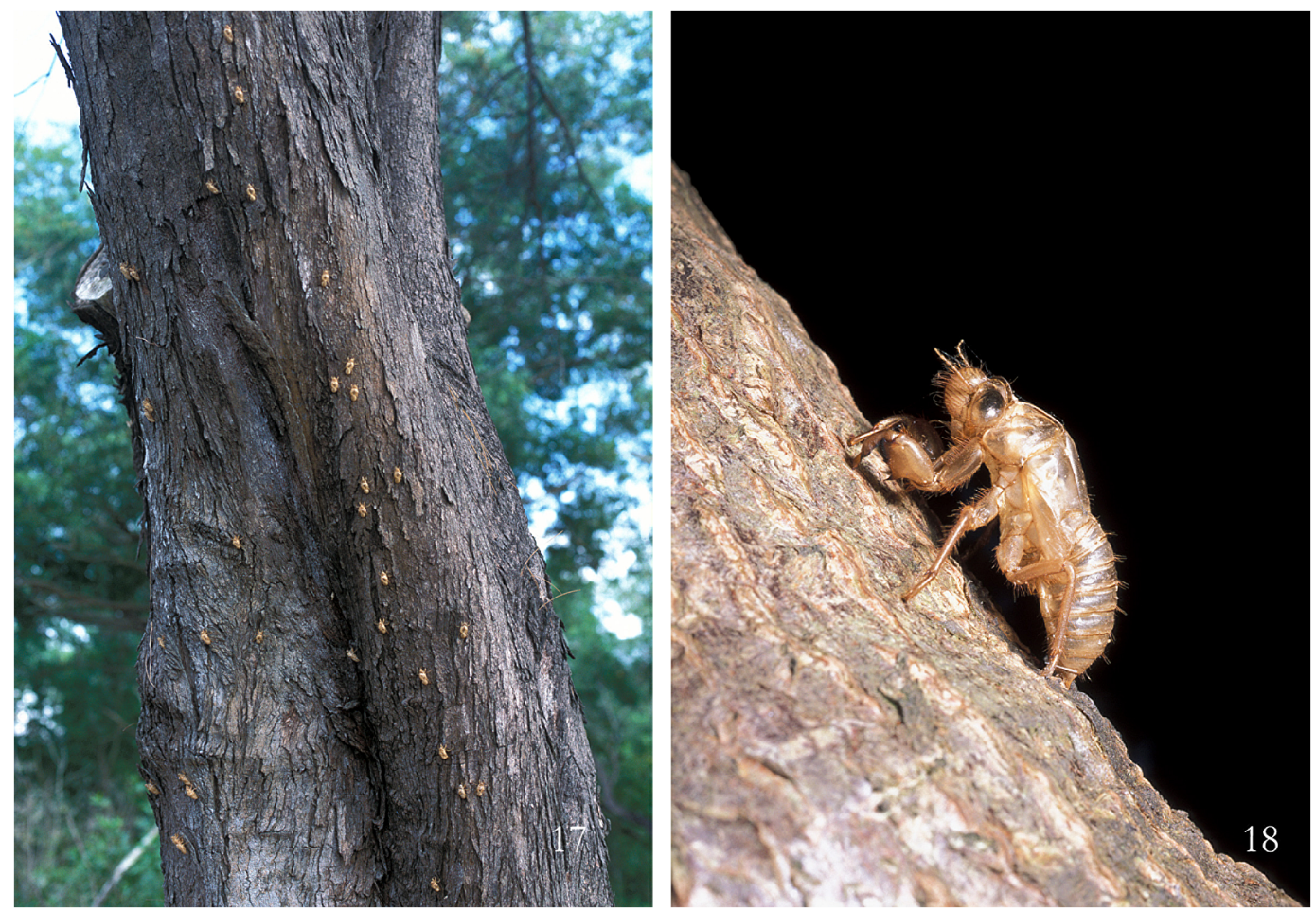

Figs 17, 18. Ayesha serva exuviae, Kota Kinabalu, Tanjung Aru. - 17, exuviae on tree trunk; 18, close-up of exuviae (photos Tomi Trilar).

individual abruptly starts singing spontaneously or stimulated by a motorboat passing by or an airplane flying over and triggers the whole chorus. That is why we did not manage to record the beginning of the song, but we observed abrupt starts which stabilizes in a second in the constant rhythm. The chorus gradually stopped singing after 10 to 20 minutes.

\section{Material examined}

Borneo: Brunei: Kampong Kapok, 22.i.1996, T.W. Harman, 2q (ZMAN), same data but 16.i.1996, 1q (ZMAN), 17.i.1996, 1q (ZMAN); Kuala Belait, 20.i.1970, M. Smart, 10 (BMNH); Penanjong coast, iii.1989, J.H. Martin, at light. B.M. 1989-89, $10^{7}$ (BMNH). Malaysia: Sabah: Jesselton [= Kota Kinabalu], i.1968, P.J.L. Roche, Brit. Mus. 1990-24, $10^{7}$ (BMNH), same data but 3.ii.1968, 20 $(\mathrm{BMNH})$, viii.1965, $20^{7} 1$ 19 (BMNH); Klagan, Kampong Lubu; $06^{\circ} 02^{\prime} 00^{\prime \prime} \mathrm{N}$, $17^{\circ} 34^{\prime} 00^{\prime \prime} \mathrm{E}, 2-3 . v .1999$ (sound record T. Trilar); Kota Kinabalu, Tanjung Aru, $05^{\circ} 54^{\prime} \mathrm{N} 116^{\circ} 04^{\prime} \mathrm{E}$, 5 m, 6.iii.2003, T. Trilar \& K. Prosenc Trilar, $50^{7}$ (PMSL), same data but 20.vi.1996, 7 exuviae (PMSL); Kudat, 5.ix.1927, ex. F.M.S. Mu- seum, B.M. 1955-354, 10 1o (BMNH), same data but 1.ix.1927, 10 (BMNH), 15.ix.1927, $10^{7}(\mathrm{BMNH})$; Labuan Is. C.T. McNamara, $10^{7}$ (SAM); Labuan Is., 10.viii.1956, L.D. Brongersma, 1을 (RMNH); Mangalum Is, N.W. Jesselton, 815.vii.1928, C. Boden Kloss, Ex. F.M.S. Museum, B.M. 1955-354, 2o (BMNH); Pulau Banguey nr. Kudat, 1.ix.1927, ex F.M.S. Museum, B.M. 1955-354, 30 (BMNH); Sandakan, 96-197, 107 (BMNH). Malaysia: Sarawak: Bako National Park, 7.v.1999, collected on the light, T. Trilar, 19 (PMSL), same data but 9.v.1999, 39 (PMSL), 13.v.1999, $10^{\top} 2$ o (PMSL); Baram, 1910, H.W. Smith, 1o (MCZ); Umg. Kuching, Bako NP, 21.ii. 1993, M. Jäch, 1o (NHMW); Santubong, Brit. Mus. 1924-86, 20 (BMNH). Indonesia: Bunguran: (= Greater Natuna Island): Ranai, Losner Ajo, $03^{\circ} 56^{\prime} 07^{\prime \prime} \mathrm{N} 108^{\circ} 23^{\prime} 00^{\prime \prime}$, $0 \mathrm{~m}$, 5.vii.2001, ca 12:00 h, coastal forest, secondary growth with coconut palms, $10 \mathrm{~m}$ from coastline, $2.5 \mathrm{~m}$ high in vegetation, handcaptured with stick and glue by Bpk Usnan for J.M. Lammertink, $10^{7}$ (ZMAN); Ranai, Losner Ajo, $03^{\circ} 56^{\prime} 07^{\prime \prime} \mathrm{N} 108^{\circ} 23^{\prime} 00^{\prime \prime}, 0$ m, 22.vii.2001, ca 12:00 h, found as fresh specimen inside hotel, 1 으 (ZMAN). Indonesia: Sulawesi: Toli Toli, xi- 

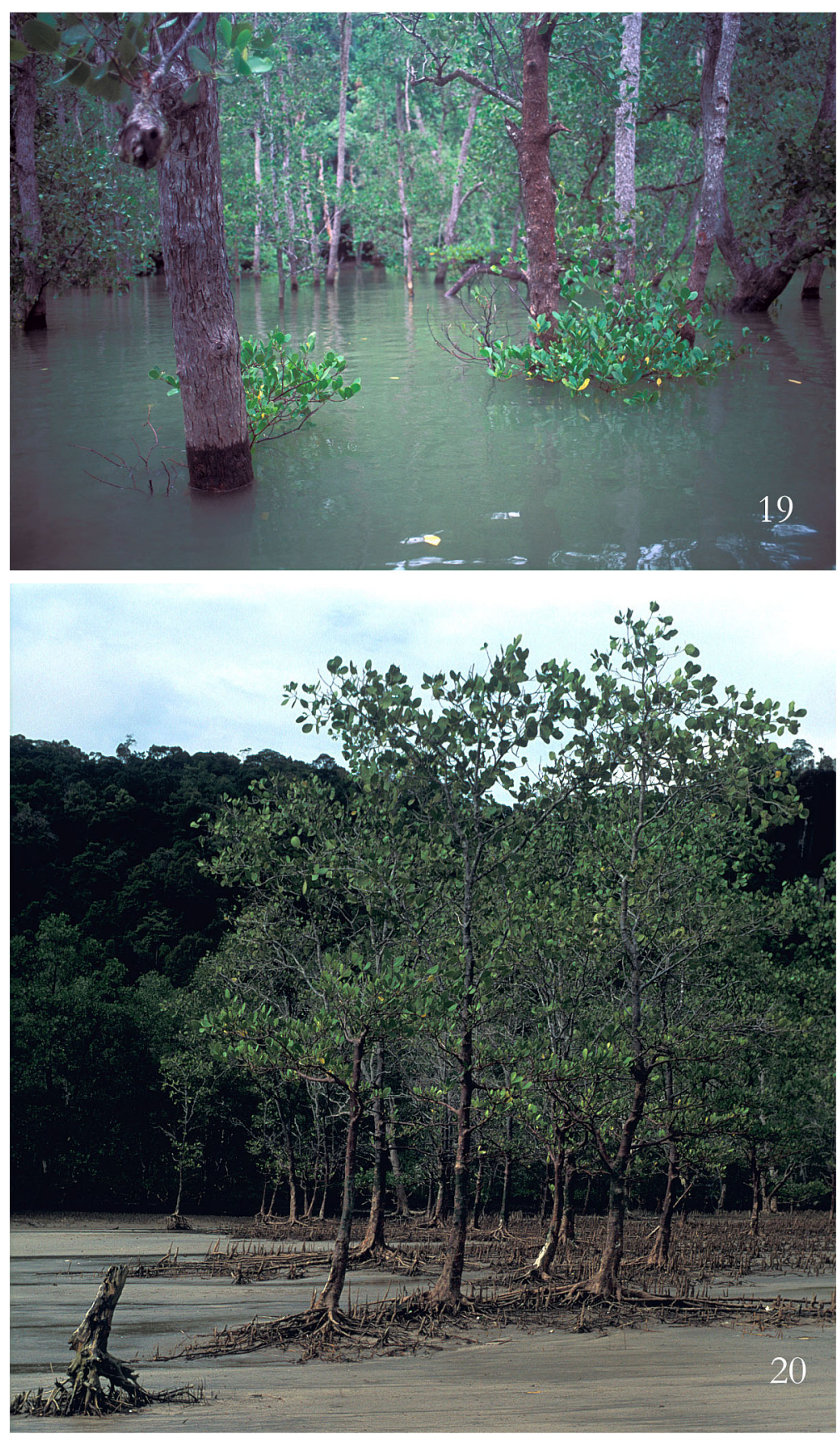

Figs 19, 20. Habitat of Ayesha serva, Telok Assam, Bako National Park, Sarawak (photos Tomi Trilar).

xii.1895, H. Fruhstorfer, Distant coll. 1911-383, spathulata Stål, $1 \sigma^{\prime}(\mathrm{BMNH})$; Toli Toli, xi-xii.1895, H. Fruhstorfer, 1909-21, 20' (BMNH); Toli Toli, xi-xii.1895, H. Fruhstorfer, 10 (MZS). Philippines: Ins. Philipp., Semper, spathulata Stål, Alloty- pus, o paralectotype of Cosmopsaltria spathulata Stål, NHRS-HEMI/000000007 (NHRS); Ins. Philipp., Semper, Cosmopsaltria spathulata Stål, Paratypus, o paralectotype of Cosmopsaltria spathulata, NHRSHEMI/000000008 (NHRS); Balabac Is.: 10 km 
S. Balabac, 18.iv.1962, H. Holtman, light trap, 2 q (BPBM), same locality, 21.iv.1962, H. Holtman $\&$ W. Sanguila, light trap, 1o (BPBM); Dalawan Bay, 4.x.1961, Noona Dan Exp. 61-61, caught by mercury light, 19:45-22:45 h, 3o (UZMK), same data but 5.x.1961, 19:30-04:00 h, 19 (UZMK), 9.x.1961, 18:30-03:00 h, 19 (UZMK), 12.x.1961, 18:30-23:30 h, 19 (UZMK). Palawan: $2 \mathrm{~km} \mathrm{~N}$ of San Rafael: $69 \mathrm{~km} \mathrm{~N}$ of Puerta Princessa, 12 m, 31.v.1984, R. Greenfield Acc. 1984.291, 1 ㅇ (BPBM). Sulu Archipelago: Sibutu Is.: Sipankot bij [= near] Siboetoe, 10-14.ix.1929, Snellius Exp., 1 \% (RMNH); Tawitawi Is.: Tarawakan, north of Batu Batu, 15.xi.1961, Noona Dan Exp. 61-62, Ayesha spathulata, $10^{7}$ (UZMK). Jolo Is.: Batu batu: 2021.ii.1957, Yoshio Kondo, 1q (BPBM).

\section{Acknowledgements}

We would like to thank Prof. Dr Matija Gogala, Slovenian Academy of Sciences and Arts, Ljubljana, Slovenia for stimulating discussions and for reading and correcting the manuscript. Special thanks goes to our wives MSc Katarina Prosenc Trilar and the late Greet Duffels van Egmond for their enormous effort during the fieldwork. We are very much indebted to the following curators for the loan and gift of material: Mr G. Nishida \& Dr Arakaki (BPBM), Dr G.F. Gross (SAM), Dr G. Lindberg (NHRS), Dr J. Matter (MZS), Dr P.D. Perkins (MCZ), Dr J. van Tol (RMNH), Mr M.D. Webb (BMNH) and Dr H. Zettel (NHMW). We specially thank Dr Gunvi Lindberg (NHRS) for providing the photographs of the types of Ayesha spathulata. We are also thankful to Dr Andrej Gogala, who did the preparation of the collected specimens for the PMSL collection. We thank Rob Portegies (ZMAN) for maintaining the database of cicada records and for making the distribution map, Dick Langerak (ZMAN) for making the drawings, and Gerard Verlaan (ZMAN) for technical assistance.

\section{References}

Anonymous, 1996. Malaysia, travel and holiday Planner. Falcon Press, Selangor Malaysia.

Anonymous, 1999. The Times comprehensive atlas of the world. - Times Books, London. 67, v, 220 pp., 124 pls.

Breddin, G., 1901. Die Hemipteren von Celebes. Ein Beitrag zur Faunistik der Insel. - Abhandlungen der naturforschenden Gesellschaft zu Halle 24: 1-213.

Distant, W.L., 1881. Descriptions of new species belonging to the homopterous family Cicadidae. - Transactions of the Royal Entomological Society 1881: 627-648.

Distant, W.L., 1888. Descriptions of new species of Oriental Homoptera belonging to the family Cicadidae. -
Annals and Magazine of Natural History (6) 1: 291298.

Distant, W.L., 1890. A monograph of Oriental Cicadidae 3: 49-72, pls 5-6. - West, Newman \& Co., London.

Distant, W.L., 1891. A monograph of Oriental Cicadidae 4: 73-96, pls 7-9. - West, Newman \& Co., London.

Distant, W.L., 1892. A monograph of Oriental Cicadidae 5: 97-120, pls 10-12. - Indian Museum, Calcutta.

Distant, W.L., 1905. Rhynchotal notes. - xxix. - Annals and Magazine of Natural History (7) 15: 58-70.

Distant, W.L., 1906. A synonymic catalogue of Homoptera. Part 1. Cicadidae. - Trustees British Museum, London, 207 pp.

Distant, W.L., 1912. Homoptera, Fam. Cicadidae, Subfam. Cicadinae. - Genera Insectorum 142: 1-64, pls $1-7$.

Duffels, J.P., 1977. A revision of the genus Diceropyga Stål, 1870 (Homoptera, Cicadidae). - Monografieën van de Nederlandse entomologische Vereniging 8: 1-227.

Duffels, J.P., 1983. Taxonomy, phylogeny and biogeography of the genus Cosmopsaltria, with remarks on the historic biogeography of the subtribe Cosmopsaltriaria (Homoptera: Cicadidae). - Pacific Insects Monograph 39: $1-127$.

Duffels, J.P., 2010. The genus Nelcyndana Stål (Hemiptera, Cicadidae, Taphurini) with description of three new species from Borneo. - ZooKeys 61: 11-31.

Duffels, J.P. \& P.A. van der Laan, 1985. Catalogue of the Cicadoidea (Homoptera, Auchenorhyncha) 19561980. - Series Entomologica 34: i-xiv, 1-414.

Duffels, J.P. \& M.I. Zaidi, 2000. A revision of the cicada genus Orientopsaltria Kato (Homoptera, Cicadidae) from Southeast Asia. - Tijdschrift voor Entomologie 142: 195-297.

Hayashi, M., 1987. A revision of the genus Cryptotympana (Homoptera, Cicadidae) Part 1. - Bulletin Kitakyushu Museum Natural History 6: 119-212.

Kirkaldy, G.W., 1902. Memoirs on oriental Rhynchota. Journal of the Bombay natural History Society 14: 4658.

Lee, Y.J., 1995. The cicadas of Korea. - Jonah Publications, Seoul, 157 pp., 9 pls.

Lee, Y.J., 1999. A systematic study on Cicadidae (Homoptera) in Korea. - Thesis, Kangwon National University, $111 \mathrm{pp}$.

Lee, Y.J., 2008. Revised synonymic list of Cicadidae (Insecta: Hemiptera) from the Korean Peninsula, with the description of a new species and some taxonomic remarks. - Proceedings of the Biological Society Washington 121: 445-467.

Lee, Y.J., 2009. A checklist of Cicadidae (Insecta: Hemiptera) in Palawan with five new species. - Journal of Natural History 43: 2617-2639.

Lee, Y.J. \& K.B.R. Hill, 2010. Systematic revision of the genus Psithyristria Stål (Hemiptera: Cicadidae) with seven new species and a molecular phylogeny of the genus and higher taxa. - Systematic Entomology 35: 277-305. 
Metcalf, Z.P., 1963. Cicadoidea. General Catalogue of the Homoptera, 8 (1), Cicadidae, section 1 Tibiceninae. North Carolina State College, Raleigh, North Carolina, vii, 585 pp.

Moulds, M.S., 2005. An appraisal of the higher classification of cicadas (Hemiptera: Cicadoidea) with special reference to the Australian fauna. - Records of the Australian Museum 57: 375-446.

Moulton, J.C., 1923. Cicadas of Malaysia. - Journal of the Federated Malay States Museum 11: 69-182, pls 1-5.

Nast, J., 1972. Palaearctic Auchenorrhyncha (Homoptera). An annotated check list. - Polish Scientific Publishers, Warszawa, 550 pp.

R Development Core Team, 2008. R: A language and environment for statistical computing. $-\mathrm{R}$ Foundation for Statistical Computing, Vienna, Austria, (http:// www.R-project.org).

Stål, C., 1870. Hemiptera insularum Philippinarum. Bidrag till Philippinska öarnes Hemipter-fauna. Öfversigt af Svenska Vetenskaps-Akademiens Förhandlingar. Stockholm 27: 607-776, pls 7-9.

Sueur, J., T. Aubin \& C. Simonis, 2008. Seewave: a free modular tool for sound analysis and synthesis. - Bioacoustics 18: 213-226.

Walker, F., 1850. List of the specimens of Homopterous insects in the collection of the British Museum 1: 1260, pls 1-2. - Trustees British Museum, London.

Received: September 20, 2012

Accepted: September 24, 2012 
